\title{
A MEASURE OF TRANSMISSION OF TUBERCULOSIS INFECTION AMONG CHILDREN IN HOUSEHOLD CONTACT
}

\author{
Sharma K R ${ }^{1}$,Bhatta N K², Niraula S R ${ }^{1}$, Gurung, $\mathbf{R}^{3}$, Pokharel, P K \\ ${ }^{1}$ School of Public Health \& Community Medicine, BP Koirala Institute of Health Science, Dharan \\ 2 Department of Paediatrics \\ ${ }^{3}$ Department of Microbiology, BP Koirala Institute of Health Science, Dharan
}

\begin{abstract}
Introduction: Tuberculosis (TB) is transmitted through droplets from patients having pulmonary TB, Young children living in the same household are at higher risk Tuberculosis, with great potential to benefit from screening and preventive treatment. This study was conducted with the objectives to estimate the prevalence of TB infection among under five years old children in household contact with pulmonary tuberculosis patients, and assess the factors associated with transmission of TB.
\end{abstract}

Methods: Pulmonary TB patients receiving treatment from the DOTS Centres in Sunsari District (Index Case-IC) were visited in their household to identify and assess contacts below five years of age. Transverse induration greater than $10 \mathrm{~mm}$ was defined as a positive Mantoux test suggestive of tubercular infection.

Results: Among 190 household contacts, Mantoux was positive in $13.7 \%(95 \% \mathrm{Cl}: 11.2-16.2)$. Higher sputum bacillary load (adjusted OR=3.03; 95\% $\mathrm{Cl} 1.01-9.1$ ) and spitting habits of Index Cases (aOR=3.1; $95 \% \mathrm{Cl} 1.2-7.7)$, first-degree relationship $(\mathrm{aOR}=3.5 ; 95 \% \mathrm{Cl} 1.4-8.7)$ and longer duration of contact (aOR$6.7 ; 95 \% \mathrm{Cl} 1.4-32.2$ ), were factors significantly associated with positive Mantoux test in the under-five years old household contact.

Conclusion: The prevalence of tuberculosis infection among under-five children in contact with pulmonary tuberculosis patients was $13.7 \%$, which is nearly double than the results of first national tuberculin survey $(7 \%)$, conducted by National Tuberculosis Centre. This highlights the need for a competent \& functioning contact tracing mechanism to halt the chain of transmission of infection. Social and behavioral factors existing in the household were significantly associated with the transmission of Tuberculosis infection.

Key words: Tuberculosis, Contact Tracing, Under Five Children.

\section{INTRODUCTION}

An estimated one million children fell ill with Tuberculosis (TB) and 170000 children died in $2015^{1}$. Children constitute $10 \%$ of the Global TB cases. ${ }^{2,3}$ Those infected with TB bacteria have a

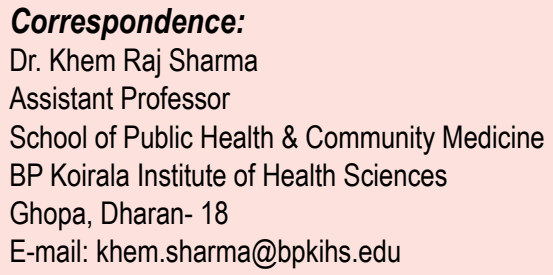

$10 \%$ lifetime risk of developing the disease. ${ }^{1}$

Ignorance and stigma among the community, insufficient contact investigation, limited access to diagnostic tests, and a host of other barriers to childhood TB diagnosis was identified by a study in Peru. While intense scientific and clinical research efforts into novel diagnostic, therapeutic and preventative interventions have focused on TB in adults, childhood TB has been relatively neglected.

However, children are particularly vulnerable to severe disease and death following infection, and those with latent infection become the reservoir of 
infection with reactivation in adulthood, fuelling the future epidemics. ${ }^{5}$ Epidemiology of childhood TB follows that of adult cases, and children constitute nearly $40 \%$ of the caseload in high incidence communities. ${ }^{6}$

Transmission of TB to young children usually results from household contact with an infectious case. $7,8,9$ Risk factors for transmission of TB in the household include a wide variety of environmental and host characteristics existing within the household. Intimacy of contact, sleeping arrangements and sputum status of the TB patient have been implicated as risk factors in the transmission of TB, or even Acute Respiratory Infection to Household Contacts, especially underfive year old children who are generally confined to the house. ${ }^{10,11,12}$ Limited social contact of very young children reduces their likelihood of becoming infected, unless the caregiver is the source case. However, additional caregivers like grandparents or extended family members taking care of the children during the day are also important. ${ }^{13}$

\section{OBJECTIVES}

To study the prevalence of Tuberculosis (TB) infection and factors associated with transmission of infection among children less than five years of age living in the same household with pulmonary TB patients of Sunsari District.

\section{METHODS}

A community-based cross-sectional study was carried out in 3 municipalities and 49 Village Development Committees (VDC) of Sunsari District, situated in south-west of Koshi zone in the eastern development region of Nepal. This district has 1, 62, 407 households with 4.7 members per household and an under five population of 68052. ${ }^{14}$ There are 14 Directly Observed Treatment Short Course (DOTS) centres and 52 sub-centres that registered 568 sputum positive and 362 sputum negative cases in this district in 2015. ${ }^{15}$

All household contacts under five years of age of newly diagnosed patients with Pulmonary TB (both sputum smear positive and negative) registered in the National Tuberculosis Program (NTP), and attending the DOTS clinics in Sunsari District were included in the study. Household contact (HC) was defined as a child less than 5 years of age, living in the same house and sharing the same kitchen as the Pulmonary TB patient. The sample size was calculated by the single proportion formula as 188 based on a similar study done in India. ${ }^{16}$ Total of 190 eligible children were enrolled in this study covering more than $95 \%$ of the total eligible household contacts of TB patients of Sunsari district.

Stratification was done at two levels- firstly all Pulmonary TB cases from the DOTS register of Sunsari district were identified (Index CaseIC),following which, house to house visits were conducted to identify eligible HC's under five years of age. A pretested semi-structured questionnaire was used to extract information from a single respondent (parents/ caretakers of the child) and a general clinical examination of both IC and $\mathrm{HC}$ were performed. Children who were already diagnosed with TB were excluded from the study.

After explaining the risks involved in the procedure, the household contacts were tested intra-dermally with $0.1 \mathrm{ml}$ of 5TU PPD with Tween 80 (SPAN Divergent Ltd, Surat, India - calibrated against Batch RT 23 manufactured by Statens Serum Institute, Denmark) and followed up in their homes within 48 to 72 hours, where the width of reaction (indurations) in the horizontal plane was noted by the pen method. Mantoux test was considered positive for indurations of $10 \mathrm{~mm}$ or more, which was suggestive of Tubercular Infection.

All children were managed according to the standard National Tuberculosis Program guidelines. ${ }^{17} \mathrm{Children}$ with positive screening result were referred to BP Koirala Institute of Health Sciences (BPKIHS), a tertiary care hospital and evaluated by the Consultant Paediatrician. They underwent chest X-ray, GeneXpert test and other relevant tests for the diagnosis of TB. Those diagnosed as TB Disease were treated under DOTS regimen, and those under-five children with TB infection were provided with Isoniazid Preventive Therapy (IPT) in the local DOTS centres.

\section{Operational definitions:}

Relationship with contact: The connection between the $\mathrm{HC}$ and the $\mathrm{IC}$, categorized as first degree (father/mother/siblings) or second degree (other than the father/mother/siblings) 
Proximity of contact: The closeness or intimacy of contact between the IC and $\mathrm{HC}$; categorized as Solitary (different room sleepers), room sharers (same room/different bed) or same surface cosleepers (same bed)

\section{Duration of contact:}

The infectious period extends from approximate dates start of TB symptoms to the period of effective treatment (demonstrated by negative sputum smears) and diminished symptoms; the duration of contact for $\mathrm{HC}$ was determined by the time they spent with the IC during the infectious period. Information from the patient interviews and other documents were assembled to assist in estimating the duration of contact.

\section{Contact ethnicity:}

The indigenous nationalities of Nepal classified based on Nepal Demographic and Health Survey $2011 .{ }^{18}$

\section{Sputum bacillary count:}

The number of TB bacilli present in sputum identified by microscopy and categorized based on American Thoracic Society guidelines into five categories.$^{19}$ Generally speaking, the sputum sample must contain 5,000 to 10,000 Acid Fast Bacilli per millilitre of specimen to be detected on Ziehl-Neelsen staining, whereas 10 to 100 organisms are needed for a positive culture. ${ }^{19}$

Injudicious spitting habits: The presence of a careless habit of spitting in and around the house in the Index case.

\section{Statistical Analysis:}

Odds Ratio(OR) with confidence limitwas calculated for inferential statistics. Logistic regression analysis was performed for all independent variables with $p$-value $<0.20$ in the bivariate analysis, This was done to identify associated factors for transmission of infection from Index Case to Household Contacts with the probability of significance set at $95 \%$ of Confidence Interval $(\mathrm{Cl})$.

Ethical approval was obtained from the Institutional Review Committee of BPKIHS at the onset of the study and permission was taken from the DOTS centres of Sunsari district to gather information on the Pulmonary TB patients. Informed written consents were obtained from the legal guardian of the children after explaining the objectives, and the methods.

Pretesting was done on $10 \%$ of the sample size not included in the final study, following which necessary corrections were incorporated. Quality was assured by calibrating the measuring instruments to check for precision during data collection, double checking for errors before entry. During entry, data was checked for completeness, coded and labelled clearly. All the procedures and observations including interviews, clinical examination and Mantoux test were performed by the Principle Investigator.

\section{RESULTS}

The study population consisted of 108 Index Cases (IC) and their 190 eligible under five contacts with Household Contact/Index Case $(\mathrm{HC} / \mathrm{IC})$ ratio of 1.76. The mean age of the IC were 44.5 years $(S D=18.05)$ and $68.5 \%$ were males. Similarly, $84(77.8 \%)$ of the IC's were sputum positive Pulmonary TB patients and $28(25.9 \%)$ had a habit of spitting injudiciously in and around the house (Table 1).

\begin{tabular}{|c|c|c|c|}
\hline \multicolumn{4}{|c|}{$\begin{array}{l}\text { Table 1: Index Case distribution by socio- } \\
\text { demographic, sputum status and personal habits }\end{array}$} \\
\hline $\begin{array}{l}\text { Character- } \\
\text { istics }\end{array}$ & Categories & $\begin{array}{l}\text { Frequency } \\
(n=108)\end{array}$ & $\begin{array}{l}\text { Percentage } \\
(\%)\end{array}$ \\
\hline \multirow{4}{*}{ Age } & $15-29$ years & 28 & 25.9 \\
\hline & 30-44 years & 30 & 27.8 \\
\hline & \begin{tabular}{|l|}
$45-59$ years \\
\end{tabular} & 22 & 20.4 \\
\hline & $\begin{array}{l}60 \text { years \& } \\
\text { above }\end{array}$ & 28 & 25.9 \\
\hline \multirow{2}{*}{ Gender } & Male & 74 & 68.5 \\
\hline & Female & 34 & 31.5 \\
\hline \multirow{2}{*}{$\begin{array}{l}\text { Sputum } \\
\text { Status }\end{array}$} & Positive & 84 & 77.8 \\
\hline & Negative & 24 & 22.2 \\
\hline \multirow{4}{*}{ Education } & Illiterate & 40 & 37.0 \\
\hline & Primary & 22 & 20.4 \\
\hline & Secondary & 31 & 28.7 \\
\hline & $\begin{array}{c}\quad \geq \\
\text { Intermediate } \\
\end{array}$ & 15 & 13.9 \\
\hline \multirow{2}{*}{$\begin{array}{c}\text { Injudicious } \\
\text { Spitting } \\
\text { Habit }\end{array}$} & Absent & 80 & 74.1 \\
\hline & Present & 28 & 25.9 \\
\hline
\end{tabular}


Mantoux test was positive in $13.7 \%(95 \% \mathrm{Cl}$ : $11.2-$ 16.2) of the household contacts. Among the HC's, $43(22.6 \%)$ shared the same bed with IC, while $133(70 \%)$ slept in different rooms. A Total of 189 $(99.5 \%)$ children gave a history of BCG vaccination, while BCG scar was visible only in $182(95.8 \%)$. Nutritional status assessed by computing with for age and graded based on Indian Academy of Paediatrics (IAP) grading for malnutrition showed 28 ( $14.7 \%)$ children to be undernourished, while severe malnutrition (grade IV) was no observed ( Table 2).

Higher sputum bacillary count (2+/3+)and presence of injudicious spitting habits in and around the house in the IC, closer relation and proximity to IC, more than 60 days duration of contact and household contacts of hill janjati ethnicity were found to be significantly associated with a positive TST on bivariate analysis (Table 3).

Goodness of fit: Chi-square $=13.8, \mathrm{df}=7, \mathrm{p}=0.054$ aOR- Adjusted Odds RatioVariable(s) entered on step 1: Sputum bacillary count, smoking \& spitting habit of IC, proximity \& relation of IC to contact, duration of exposure and ethnicity of contact.

Presence of injudicious spitting habit of IC [adjusted $\mathrm{OR}=3.1 ; 95 \% \mathrm{Cl}(1.2-7.7) ; \mathrm{p}-0.016]$, first degree relationship between $\mathrm{IC}$ and contact $[\mathrm{aOR}=3.5$; $95 \% \mathrm{Cl}(1.4-8.7) ; p-0.009]$, higher sputum bacillary load $(2+/ 3+)$ [aOR $=3.03 ; 95 \% \mathrm{Cl}(1.01-9.1) ; p-0.048]$ and duration of contact with IC more than 60 days $[\mathrm{aOR}=6.7 ; 95 \% \mathrm{Cl}(1.4-32.2) ; \mathrm{p}-0.018]$ remained significant in the logistic regression analysis after adjusting for other variables (Table 4).

\begin{tabular}{|c|c|c|c|}
\hline Characteristics & Categories & $\begin{array}{c}\text { Frequency } \\
(n=190)\end{array}$ & $\begin{array}{c}\text { Percentage } \\
(\%)\end{array}$ \\
\hline \multirow{2}{*}{ Age Groups } & $<3$ years & 100 & 52.6 \\
\hline & 3 year -5 years & 90 & 47.4 \\
\hline \multirow{2}{*}{ Gender } & Male & 101 & 53.2 \\
\hline & Female & 89 & 46.8 \\
\hline \multirow{3}{*}{$\begin{array}{l}\text { Proximity } \\
\text { to IC }\end{array}$} & $\begin{array}{l}\text { Solitary (Different } \\
\text { Room Sleepers) }\end{array}$ & 133 & 70 \\
\hline & $\begin{array}{l}\text { Room Sharers } \\
\text { (Same Room/ } \\
\text { Diff. bed) }\end{array}$ & 14 & 7.4 \\
\hline & $\begin{array}{l}\text { Same Surface } \\
\text { Co-sleepers } \\
\text { (Same bed) }\end{array}$ & 43 & 22.6 \\
\hline \multirow{2}{*}{ Overcrowding } & Present & 146 & 76.8 \\
\hline & Absent & 44 & 23.2 \\
\hline \multirow{2}{*}{$\begin{array}{l}\text { Socio- } \\
\text { Economic } \\
\text { Status }\end{array}$} & $\begin{array}{l}\text { Below poverty } \\
\text { line }(<1.9 \$ \text { /day })\end{array}$ & 182 & 95.8 \\
\hline & $\begin{array}{l}\text { Above poverty } \\
\text { line }(\geq 1.9 \$ / \text { day })\end{array}$ & 8 & 4.2 \\
\hline \multirow{2}{*}{ BCG Scar } & Present & 182 & 95.8 \\
\hline & Absent & 8 & 4.2 \\
\hline \multirow{4}{*}{$\begin{array}{c}\text { IAP } \\
\text { classification } \\
\text { for } \\
\text { Malnutrition }\end{array}$} & Normal $(>80)$ & 162 & 85.3 \\
\hline & Grade I (71-80) & 18 & 9.5 \\
\hline & Grade II (61-70) & 9 & 4.7 \\
\hline & Grade III (51-60) & 1 & 0.5 \\
\hline \multirow[t]{2}{*}{$\begin{array}{l}\text { Mantoux } \\
\text { Test (TST) }\end{array}$} & $\begin{array}{l}\text { Positive } \\
(\geq 10 \mathrm{~mm})\end{array}$ & 26 & 13.7 \\
\hline & $\begin{array}{l}\text { Negative } \\
(<10 \mathrm{~mm})\end{array}$ & 164 & 86.3 \\
\hline
\end{tabular}

\begin{tabular}{|c|c|c|c|c|c|c|c|c|}
\hline \multirow[t]{2}{*}{ Characteristic } & \multirow{2}{*}{ Category } & \multicolumn{2}{|c|}{ Mantoux Test } & \multirow{2}{*}{$\begin{array}{c}\text { Total } \\
(n=190)\end{array}$} & \multirow{2}{*}{ OR } & \multicolumn{2}{|c|}{$95 \% \mathrm{Cl}$} & \multirow{2}{*}{$\begin{array}{c}\text { Significance } \\
\text { (p-value) }\end{array}$} \\
\hline & & Negative & Positive & & & Lower & Upper & \\
\hline \multirow{2}{*}{$\begin{array}{l}\text { Sputum Bacillary } \\
\text { Count }(n=144)\end{array}$} & $0 / 1+$ & 93.7 & 6.3 & 79 & 1.0 & & & \\
\hline & $2+/ 3+$ & 81.1 & 18.9 & 111 & 3.45 & 1.2 & 9.6 & 0.013 \\
\hline \multirow{2}{*}{ IC spitting Habit } & No & 91.8 & 8.2 & 134 & 1.0 & & & \\
\hline & Yes & 73.2 & 26.8 & 56 & 4.09 & 1.74 & 9.6 & 0.001 \\
\hline \multirow{2}{*}{ Proximity to IC } & Diff. Room & 90.2 & 9.8 & 133 & 1.0 & & & \\
\hline & Same Room & 77.2 & 22.8 & 57 & 2.7 & 1.17 & 6.3 & 0.017 \\
\hline \multirow{2}{*}{ Duration of Contact } & $\leq 60$ days & 95.7 & 4.3 & 47 & 1.0 & & & \\
\hline & $>60$ days & 83.2 & 16.8 & 143 & 4.5 & 1.03 & 19.9 & 0.03 \\
\hline \multirow{2}{*}{ Relation with IC } & $2^{\text {nd }}$ Degree & 91.0 & 9.0 & 122 & 1.0 & & & \\
\hline & $1^{\text {st }}$ Degree & 77.9 & 22.1 & 68 & 2.8 & 1.22 & 6.6 & 0.012 \\
\hline \multirow{2}{*}{ Contact Ethnicity } & Others & 90.9 & 9.1 & 110 & 1.0 & & & \\
\hline & Hill Janjati & 80.0 & 20.0 & 80 & 2.5 & 1.07 & 5.8 & 0.031 \\
\hline
\end{tabular}




\begin{tabular}{|c|c|c|c|c|c|}
\hline \multirow{2}{*}{ Characteristics } & \multirow{2}{*}{ Category } & \multirow{2}{*}{$\begin{array}{c}\text { Adjusted OR } \\
\text { (aOR) }\end{array}$} & \multicolumn{2}{|c|}{$95 \% \mathrm{Cl}$} & \multirow{2}{*}{$\begin{array}{l}\text { Significance } \\
\text { (p-value) }\end{array}$} \\
\hline & & & Lower & Upper & \\
\hline \multirow{2}{*}{ Relation of Contact to IC } & Second Degree & 1 & & & \\
\hline & First Degree & 3.5 & 1.4 & 8.7 & 0.009 \\
\hline \multirow{2}{*}{ IC Spitting Habit } & Absent & 1 & & & \\
\hline & Present & 3.1 & 1.2 & 7.7 & 0.016 \\
\hline \multirow{2}{*}{$\begin{array}{l}\text { Sputum Bacillary } \\
\text { Count of IC }\end{array}$} & Low bacillary count $(0 / 1+)$ & 1 & & & \\
\hline & High Bacillary Count $(2+/ 3+)$ & 3.03 & 1.01 & 9.1 & 0.048 \\
\hline \multirow{2}{*}{ Duration of Contact } & $\leq 60$ days & 1 & & & \\
\hline & $>60$ days & 6.7 & 1.4 & 32.2 & 0.018 \\
\hline
\end{tabular}

\section{DISCUSSION}

Higher risk of infection among household contacts of Pulmonary TB patients than the general population have been reported earlier ${ }^{11,16,21,22 \text {, }}$ ${ }^{23}$ This study reports $13.7 \%$ (95\% Cl:11.2-16.2) transmission of Tuberculosis infection to under five year old HC's of Pulmonary TB patients established by a positive Mantoux Test $(\geq 10$ $\mathrm{mm}$ ) and factors associated with it. This is in contrast with the first national survey done in Nepal, which presented a national prevalence of infection of $7.0 \%(95 \% \mathrm{Cl}: 4.2-9.7){ }^{24}$ This warrants for a strong contact tracing mechanism in the National Tuberculosis Program (NTP) to curb the transmission of Infection. Although contact tracing has already been introduced in Nepal in recent years, its implementation in the field remains to be seen.

The intimacy of contact with the IC also has bearings on transmission of infection and more the intimacy, greater the chances of infection. Bed sharing has been shown to transmit respiratory infections in a study from The Gambia. ${ }^{12}$ Similarly, the intimacy of contact as judged by sleeping in the same room with the Index case increased the chances of contact having a positive Mantoux Test by 2.7 times in this study. [OR=2.7; $95 \% \mathrm{Cl}(1.2-6.3)$; $p=0.017]$. Similar results have been demonstrated by another study on older HCs in Dharan. ${ }^{25}$ These findings points to the fact that proper care of young children needs to be highlighted in counselling Pulmonary TB patients at DOTS centres.

Social determinants, habits, traditions and customs increase the risk of infection among certain ethnic population as demonstrated by a study in Greenland. ${ }^{26} \mathrm{Hill}$ Adibasi/Janajati (disadvantaged indigenous nationalities of the hills)are a dominant ethnic group in Nepal comprising $27.3 \%$ of the total population. ${ }^{27}$ The National Legal Code (Muluki Ain) proclaimed in the period of autocratic Rana rule in $1854 \mathrm{AD}$ categorized them as non-enslavable matwali (liquor drinkers) based on their fondness for alcohol. ${ }^{28} \mathrm{An}$ extended analysis of Nepal Demographic and Health Survey 2006 revealed that $43 \%$ of the women of this ethnicity cited lack of money for treatment as a problem in accessing health care.. Only $80 \%$ children of this ethnicity received all basic vaccinations compared to $92 \%$ for Hill Brahmins. ${ }^{28}$

According to the findings of this study, Hill Janjati contacts under five years were 2.5 times more likely to have a positive TST [OR=2.5; $95 \% \mathrm{Cl}(1.07-5.8)$ : $p=0.031$ ] than other ethnicities of Sunsari district. Higher rate of transmission of TB bacilli could be explained on the basis of their social customs and consistently lesser access to and use of a range of health services. Further, little is known about the genetic susceptibility to tuberculosis, but studies have reported that polymorphisms in the genes for the interferon gamma receptor are associated with susceptibility. ${ }^{29}$ This association of ethnicity of the Household Contacts with a positive Mantoux test could be explained by these findings of genetic and socio-cultural differences. However more research is required to explore this finding.

Grading of sputum smear, a quantitative measure of TB bacilli in the sputum samples, has been suggested as a parameter that can represent the severity and the infectiousness of the disease. Dissemination of increasing number of tubercle bacilli from an infectious case results in higher risk of infection in under-five contacts. Presence of TB bacilli in the sputum of the Index case and the bacillary load in the sputum have been implicated in the transmission of tuberculosis infection in 
various studies. ${ }^{11,16,21,22,30}$ This study similarly demonstrated this fact, where higher the load of sputum bacilli $(2+/ 3+)$ of the IC, more likely the transmission to household contacts. [aOR=3.03; $95 \% \mathrm{Cl}(1.01-9.1): p=0.048]$

The presence of injudicious spitting habits in and around the house by IC showed a 3.1 times greater chance of the $\mathrm{HC}$ acquiring the infection [aOR=3.1; $95 \% \mathrm{Cl}(1.2-7.7): p=0.016]$ This calls for stringent legal and regulatory measures to outlaw spitting at public places to prevent the spread of Tuberculosis and other air borne pathogens. Notices declaring spitting as illegal and the cause for spread of Tuberculosis were publicized as early as 1900 AD. ${ }^{31}$ Many experts at that time believed that spitting was the sole cause for spread of disease among mankind and New York Department of Health began to conduct anti-spitting campaigns to transform this traditional habit from annoyance into a public health threat. ${ }^{32}$ Recent study from India has shown quite a large proportion(49.2\%) of the study population practicing injudicious spitting. ${ }^{33}$ This plays a role in the spread of $\mathrm{TB}$, as the organism can survive for prolonged periods outside the human body. Patients with correct knowledge regarding hazards of indiscriminate sputum disposal had significantly better practice of appropriate sputum disposal as compared to patients with incorrect knowledge $(p=0.0001)$ in a study from India. ${ }^{34}$ This calls for Behavior Change Communication activities to curb this practice common in Nepal.

The closeness of relation of contact to the Index case has been implicated in transmission of infection in some studies. 10,11,22, 30 First degree relationships (spouse/son/daughter of the Index case) provide closer contact between IC and $\mathrm{HC}$, increasing the chances of transmission of infection. First degree relations also tend to live together within the same household in closed spaces, resulting in higher chances of infection. Closer relationship of the contact to IC (first degree) [aOR=3.5; 95\% $\mathrm{Cl}(1.4-8.7): \mathrm{p}=0.009$ ] was found to be associated with transmission of TB infection to HC's. Similar results have been observed in studies conducted in Indonesia ${ }^{30}$ and Nepal. ${ }^{25}$

Greater duration of contact ( $>60$ days) between the $\mathrm{IC}$ and $\mathrm{HC}$ was found to be 6.18 times more likely to result in a positive TST in this study [aOR=6.7; $95 \% \mathrm{Cl}(1.4-32.2) ; p=0.018]$. This follows the fact that longer duration of exposure results in more chances of transmission due to prolonged exposure. This fact has also been highlighted by some studies. . $^{35,36}$

\section{CONCLUSION}

The findings of this study emphasize the importance of integrating behaviour change communication activities during counselling of Pulmonary TB patients at DOTS centres on infection prevention measures (proper sputum disposal) and good care of young children in the household. This will serve as a cost-effective means to curb the transmission of TB infection to young children in those households.

\section{LIMITATION OF THE STUDY}

The sampling frame included only TB patients registered in national DOTS Registers, which could have excluded pulmonary TB patients and their contacts managed solely in private sectors. Although a negative history of HIV was obtained in all subjects, HIV testing was not feasible due to time and resource constraints. Toddlers $(<3$ years) are usually confined to the household, however, older children (4-5 years) could have been exposed to TB case while playing outside of the house, although a negative history of exposure outside the household was obtained in all subjects.

\section{CONFLICT OF INTEREST}

None

\section{FUNDING}

None

\section{ACKNOWLEDGEMENT}

The authors would like to thank National Tuberculosis Centre, Nepal and its various centres and sub-centres for providing access to the DOTS registers. Similarly, credit goes to BP Koirala Institute of Health Sciences for its support in the execution of this research. Last but foremost; the authors are indebted to the PTB patients of Sunsari District and their house-holds for whole-hearted cooperation in this research. 


\section{REFERENCES}

1. WHO factsheet available at http://www.who.int/ mediacentre/factsheets/fs 104/en/ and accessed on $21 / 6 / 2017$

2. Lönnroth K, Castro K G, Chakaya J M, Chauhan LS, Floyd K, Glaziou P et al. Tuberculosis control and elimination 2010-50: cure, care and social development. Lancet 2010; 375: 1814-1829.

3. Marais B J, Gie R P, Schaaf H S, Beyers N, Donald PR, Starke J R. Childhood pulmonary tuberculosis: old wisdom and new challenges. Am J Respir Crit Care Med 2006; 173: 1078-1090

4. Chiang SS, Roche S, Contreras C, Alarcón V, Del Castillo $H$, Becerra MC et al.Barriers to the diagnosis of childhood tuberculosis: a qualitative study. INT J TUBERC LUNG DIS 19(10):11441152

5. Newton SM, Brent AJ, Anderson S, Whittaker E, Kampmann B. Paediatric tuberculosis. The Lancet infectious diseases. 2008 Aug;8(8):498-510.

6. Kabra SK, Lodha R, Seth V. Some current concepts on childhood tuberculosis. The Indian journal of medical research. 2004 Oct;120(4):387-97

7. Bloch A B, Snider D E, Jr. How much tuberculosis in children must we accept? Am J Public Health 1986; 76: 14-15

8. Devadatta S,Dawson JJY, Fox W, Janardhanam B, Radhakrishna S, Ramakrishnan CV et al. Attack rate of tuberculosis in a 5-year period among close family contacts of tuberculous patients under domiciliary treatment with isoniazid plus PAS or isoniazid alone. Bull World Health Organ. 1970;42:337-351

9. Starke JR, Jacobs RF, Jereb J. Resurgence of tuberculosis in children. J Pediatr. 1992;120:839855

10. Khan PY, Glynn JR, Fielding KL, Mzembe T, Mulawa D, Chiumya $R$ et al. Risk factors for Mycobacterium tuberculosis infection in 2-4 year olds in a rural HIV-prevalent setting INT J TUBERC LUNG DIS 20(3):342-349

11. Lienhardt C, Sillah J, Fielding K, Donkor S, Manneh K, Warndorff D, Bennett S, McAdam K. Risk Factors for Tuberculosis Infection in Children in Contact With Infectious Tuberculosis Cases in The Gambia, West Africa. Pediatrics. 2003 May;111(5 Pt 1):e608-14.

12. Howie SR, Schellenberg J, Chimah $O$, Ideh $\mathrm{RC}$, Ebruke BE, Oluwalana $\mathrm{C}$ et al; Childhood pneumonia and crowding, bed-sharing and nutrition: a case-control study from The Gambia. INT J TUBERC LUNG DIS 20(10):1405-1415

13. Miller FJW, Seal RME, Taylor MD. Tuberculosis in children.London, UK: J and A Churchill Ltd, 1963: 79-163
14. National Population \& Housing Census 2011, CBS, Nepal, available at http://cbs.gov.np/sectoral_ statistics/population/national_report, accessed on $12 / 3 / 2017$

15. National Tuberculosis Centre, Nepal Annual Report accessed on 20/4/2017, available at http://www.nepalntp.gov.np/theme/images/ uploads/1463382367NNUAL_REPORT_2015.pdf

16. Singh M, Mynak ML, Kumar L, Mathew JL, Jindal SK. Prevalence and risk factors for transmission of infection among children in household contact with adults having pulmonary tuberculosis. Arch Dis Child. 2005 Jun;90(6):624-8.

17. National Tuberculosis Centre, Nepal. NTP Clinical Manuals available at http://www.nepalntp.gov. np/theme/images/uploads/1373874048linical_ Manual.pdf and accessed on 22/4/2017

18. Nepal Demographic and Health Survey 2011. Department of Health Services. available at http://dhsprogram.com/pubs/pdf/fr257/ fr257\%5B13april2012\%5D.pdf and accessed on 17/6/2017.

19. American Thoracic Society. Diagnostic Standards and Classification of Tuberculosis in Adults and Children. Am J Respir Crit Care Med. 2000 Apr;161(4 Pt 1):1376-95.

20. Proceedings of the Workshop on Protein Calorie Malnutrition. Ecology and Management. Indian Pediatr. 1975;12(1):57-117.

21. Mtombeni $S$, Mahomva A, Siziya $S$, Sanyika C, Doolabh R, Nathoo KJ.A clinical evaluation of children under the age of five years who are household contacts of adults with sputum positive tuberculosis in Harare, Zimbabwe.Cent Afr J Med. 2002 Mar-Apr;48(3-4):28-32

22. Sinfield R, Nyirenda M, Haves S, Molyneux EM, Graham SM. Risk factors for TB infection and disease in young childhood contacts in Malawi. Annals of Tropical Paediatrics (2006) 26, 205-213

23. Grzybowski S, Barnett GD, Styblo K. Contacts of cases of active pulmonary tuberculosis. Bull Int Union Tuberc Lung Dis. 1975;5:90-106

24. Shrestha KB, Malla P, Jha KK, Shakya TM, Akhtar M, Gunneberg C, Van der Werf MJ. First national tuberculin survey in Nepal. INT J TUBERC LUNG DIS 12(8):909-915

25. Gyawali N, Gurung R, Poudyal N, Amatya R, Niraula SR, Jha Pet al. Prevalence of tuberculosis in household contacts of sputum smears positive cases and associated demographic risk factors. Nepal Med Coll J 2012; 14(4): 303-307

26. Soborg $B$, Andersen AB, Melbye M, Wohlfahrt J, Andersson M, Biggar RJ, et al. Risk factors for Mycobacterium tuberculosis infection among children in Greenland. Bulletin of the World Health Organization. 2011 Oct 1;89(10):741-8, 8A-8E. 
27. CBS, Nepal 2014. Population Monograph of Nepal (Volume II) available at http://cbs.gov.np/image/ data/Population/Population\%20Monograph $\% 20$ of $\% 20 \mathrm{Nepal} \% 202014 / \mathrm{P}$ opulation $\% 20$ Monograph\%20V02.pdf accessed on 20/5/2017.

28. Bennett L, Dahal DR, Govindasamy P. Caste, Ethnic and Regional Identity in Nepal - Further Analysis of the 2006 Nepal Demographic and Health Survey available at http://pdf.usaid.gov/ pdf_docs/Pnadm638.pdf, accessed on 19/5/2017.

29. Cooke GS, Campbell SJ, Sillah J, Gustafson P, Bah B, Sirugo G, et al. Polymorphism within the interferon-gamma/receptor complex is associated with pulmonary tuberculosis. American journal of respiratory and critical care medicine. 2006 Aug 1;174(3):339-43.

30. Rutherford ME, Hill PC, Maharani W, Apriani L, Sampurno van Crevel HR, Ruslami R. Risk factors for Mycobacterium tuberculosis infection in Indonesian children living with a sputum smear-positive case. INT J TUBERC LUNG DIS 16(12):1594-1599

31. Abrams JE. "Spitting Is Dangerous, Indecent, and against the Law!" Legislating Health Behavior during the American Tuberculosis Crusade. Journal of the History of Medicine and Allied Sciences, Volume 68, Number 3
32. Chapman S. Great Expectorations! The decline of public spitting: Lessons for passive smoking? BMJ 1995; 311:1685

33. Bhattacharyya K, Ram R, Mitra SP, Bhattacharyya SK, Sarkar TK, Dasgupta U, Goswami DN. Perceptions and Practices of Sputum Positive Pulmonary Tuberculosis Patients regarding their Disease and its Management. NTI Bulletin 2005,41/1\&2, 11 - 17

34. Shukla AA, Chauhan SR, Dalal AP. Study of Knowledge and Practice of Sputum Disposal among TB Patients of Ahmedabad City. NHL Journal of Medical Sciences 2013;2(2):22-25

35. Kashyap RS, Nayak AR, Gaherwar HM, Husain AA, Shekhawat SD, Jain RKet al. Latent TB infection diagnosis in population exposed to TB subjects in close and poor ventilated high TB endemic zone in India. PLoS One. 2014 Mar 10;9(3):e89524.

36. Xu J, Hu Y, Jiang W, Hong J, Tang L, Yang M et al. Prevalence and risk factors of latent tuberculosis infection in close contacts of tuberculosis patients among non-resident populations in Shanghai, China. Chinese Journal of tuberculosis and respiratory disease. 2016 Jan;39(1):25-9. 